\title{
Bibliometric Analysis of Published Literature on Industry 4.0
}

\author{
Aidi Ahmi \\ Tunku Puteri Intan Safinaz School of Accountancy \\ Universiti Utara Malaysia \\ 06010 UUM Sintok, Kedah, Malaysia \\ aidi@uum.edu.my
}

\author{
Hany Elbardan \\ Faculty of Management, Bournemouth Business School \\ Bournemouth University \\ 89 Holdenhurst Road, Bournemouth BH8 8EB \\ helbardan@bournemouth.ac.uk
}

\author{
Raja Haslinda Raja Mohd Ali \\ Tunku Puteri Intan Safinaz School of Accountancy \\ Universiti Utara Malaysia \\ 06010 UUM Sintok, Kedah, Malaysia \\ rj.linda@uum.edu.my
}

\begin{abstract}
Research on Industry 4.0 was initiated in 2012. Since then, the term "Industry 4.0 " has been widely used among researchers to further investigate the development of technologies in the related industry. Thus, the aim of this study is to analyze the scientific literature published in the field of Industry 4.0. Scopus database was utilized to collect all literature in Industry 4.0. Publish or Perish software was used to incorporate the obtained data, while VOSviewer was used for data visualization. SPSS and Microsoft Excel were employed for data analysis. The growth of publications, research productivity and citation analysis were presented using standard bibliometric analysis. Based on the search results, a total of 1256 documents were retrieved. The growth rate of literature in Industry 4.0 increased drastically year by year since 2012. Most of the articles were published in journals and conferences, mainly in English. Most of the research in Industry 4.0 was in the engineering field. Keywords of the Internet of Things (IoT) and Cyber-Physical Systems (CPS) were the most keywords used and represent the main areas of research covered in Industry 4.0. Most of the research related to Industry 4.0 was conducted in Germany and multi-authored with a mean collaboration index of $\mathbf{3 . 6 5}$ authors per article. This study presents the evolution of the scientific literature in Industry 4.0 and identifies areas of current research interests and potential directions for future research.
\end{abstract} Review

Keywords-Industry 4.0; Bibliometric Analysis; Systematic

\section{INTRODUCTION}

Industry 4.0 (also known as the 4th Industry) is a current trend of automation and data exchange in manufacturing technologies after mechanization (1st Industry), mass production (2nd Industry), and computer and automation (3rd Industry). It transforms manufacturing into a digital, smart manufacturing processes that makes it possible to gather and analyze data across machines, enabling faster, more flexible, and more efficient processes to produce higher-quality goods at reduced costs. Further, it has changed the competitiveness of companies through increase productivity, shift economics, and foster industrial capabilities. Nine technology trends form the Industry 4.0 namely autonomous robots, simulation, horizontal and vertical system integration, internet of things (IoT), cybersecurity, cloud computing, big data and analytics, additive manufacturing, and augmented reality. These technologies do not only transform the communication and relationships among suppliers, customers, and manufacturers but also between human and machine.

The research in Industry 4.0 was initiated in 2012. Since then, this term has been widely used among researchers to further investigate the development of technologies in the related industry. Thus, the aim of this study is to analyze the scientific literature published in the field of Industry 4.0 using bibliometric analysis. Bibliometric analysis is a quantitative method used to examine the knowledge structure and development of research fields based on analysis of related publications [1]. Pritchard, [2] defines bibliometrics as "the application of mathematics and statistical methods to books and other media of communication".

This section explains the purpose of conducting a bibliometric analysis while the second section details out the methodology adopted. The third section presents the results of the relevant bibliometric indicators. The last section summaries the findings, identifies future research areas and presents some limitations of this study.

\section{METHODS}

This study collected all data from Scopus database as at $6^{\text {th }}$ October 2018. Scopus database has been used as it is the "largest single abstract and indexing database ever built" [3] and the largest searchable citation and abstract source of searching 
literature [4]. Some of the analytical results have been obtained from the collected documents such as access type, year, author name, subject area, document type, source title, keywords, affiliation, country, source type and language. For the purpose of this study, we focused on all documents related to the Industry 4.0 which were based on the title of the document. As such, the following query was conducted: (TITLE("Industry $4.0 ")$ ). This query produced a total of 1262 documents. However, after data cleaning i.e. by removing some duplicates there was a total of 1256 documents for further analyze.

\section{RESULTS}

The data collected were analyzed to identify document types, source types, annual growth, languages, subject areas, keywords, countries' productivity, authorships, and citations. Most of the findings presented as frequency and percentage. For annual growth, we presented data as the number of retrieved documents per year including their frequency, percentage and cumulative percentage until $6^{\text {th }}$ October 2018.

\section{A. Document and Source Types}

Data obtained were analyzed first to identify its document types and source types. Document types include conference papers, articles, and book chapters, while source types are journals, conference proceedings, book series, books or trade publications. The conference papers that appeared under document type were different from those appeared under source type [5]. Within document type, conference papers refer to papers presented in conferences and were probably published as full journal articles. Some conference papers were also published either in conference proceedings or as a book chapter within source type although the document type was originated from a conference paper.

This study found 10 types of documents that have been published related to Industry 4.0 namely, conference papers, articles, book chapters, editorials, short surveys, notes, articles in press, reviews, books, and conference reviews. As per Table I, the majority of publications were from conference papers represented by $41.96 \%$, followed by articles, $38.06 \%$. The other types of documents collectively represented by almost $20 \%$, where each type was less than $5 \%$ of total documents. The lowest two types were books and conference reviews, with less than $1 \%$ each.

TABLE I. DOCUMENT TYPE

\begin{tabular}{|l|c|c|}
\hline Document Type & Frequency & \% \\
\hline Conference Paper & 527 & 41.96 \\
\hline Article & 478 & 38.06 \\
\hline Book Chapter & 62 & 4.94 \\
\hline Editorial & 45 & 3.58 \\
\hline Short Survey & 40 & 3.18 \\
\hline Note & 38 & 3.03 \\
\hline Article in Press & 34 & 2.71 \\
\hline Review & 29 & 2.31 \\
\hline Book & 2 & 0.16 \\
\hline Conference Review & 1 & 0.08 \\
\hline Total & $\mathbf{1 2 5 6}$ & $\mathbf{1 0 0 . 0 0}$ \\
\hline
\end{tabular}

Table II presents five source types . The highest represented type is journals $(43.39 \%)$, followed by conference proceedings with $32.25 \%$. Book series and trade publications also contribute a quite significant number of documents represented by $12.26 \%$ and $10.51 \%$, respectively. The lowest contribution was from books.

TABLE II. SOURCE TYPE

\begin{tabular}{|l|c|c|}
\hline Source Type & Frequency & \% \\
\hline Journals & 545 & 43.39 \\
\hline Conference Proceedings & 405 & 32.25 \\
\hline Book Series & 154 & 12.26 \\
\hline Trade Publications & 132 & 10.51 \\
\hline Books & 20 & 1.59 \\
\hline Total & $\mathbf{1 2 5 6}$ & $\mathbf{1 0 0 . 0 0}$ \\
\hline
\end{tabular}

\section{B. Year of Publications}

The first research on Industry 4.0 was published in 2012 by Hofmann, Margull, Dittrich and Düntsch [6] with their paper titled, "Smartphone green vision at dawn of industry 4.0". The growth of the related publications has then risen gradually in 2013 and 2014. However, it was drastically increased (as shown in Fig. 1). Based on Fig. 1, it is expected that the number of publications during 2018 will increase more to be even the highest number of publications since 2012. As for 2019, although the year is still in the future, however, some publications have already been scheduled and indexed in the Scopus database.

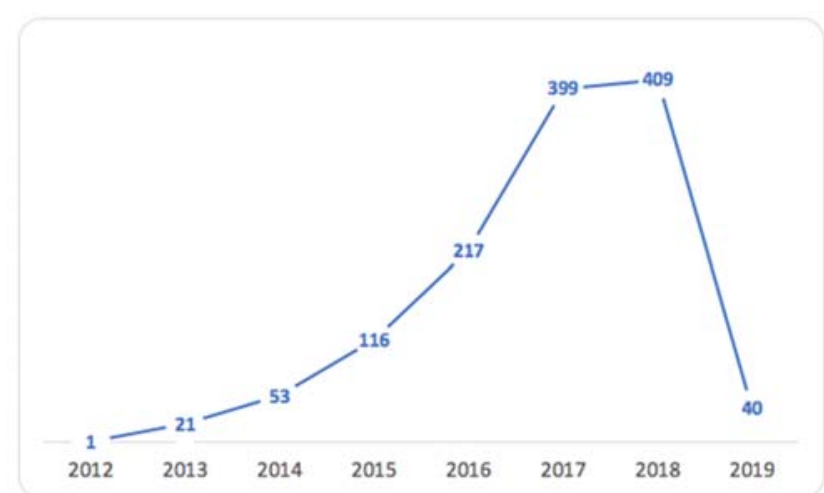

Fig. 1. Total Number of Publications by Year

\section{Languages of Documents}

Table III shows that most of the retrieved documents (more than $90 \%$ ) were published in English (90.29\%). However, some documents were published in dual languages such as English and German (146); English and Portuguese (5); English and French (2); English and Spanish (2); and English and Italian (1). Some other papers were published in a single language such as German, Chinese, Russian and Spanish. Czech and Turkish languages were the most unpopular languages in the papers studied. 
TABLE III LANGUAGES

\begin{tabular}{|l|c|c|}
\hline Language & Frequency & Percent \\
\hline English & 978 & 77.87 \\
\hline English; German & 146 & 11.62 \\
\hline German & 89 & 7.09 \\
\hline Chinese & 7 & 0.56 \\
\hline Russian & 7 & 0.56 \\
\hline Spanish & 7 & 0.56 \\
\hline English; Portuguese & 5 & 0.40 \\
\hline Portuguese & 4 & 0.32 \\
\hline Italian & 3 & 0.24 \\
\hline Japanese & 3 & 0.24 \\
\hline English; French & 2 & 0.16 \\
\hline English; Spanish & 2 & 0.16 \\
\hline Czech & 1 & 0.08 \\
\hline English; Italia & 1 & 0.08 \\
\hline Turkish & 1 & 0.08 \\
\hline Total & $\mathbf{1 2 5 6}$ & $\mathbf{1 0 0 . 0 0}$ \\
\hline
\end{tabular}

\section{Subject Area}

This study also tabled the published documents based on its subject areas. Most of the studies on Industry 4.0 were in the area of engineering representing $66.08 \%$ of the total documents followed by computer science $(42.36 \%)$, business, management and accounting (19.9\%), and decision sciences (16.4\%). The other subject areas covered in Industry 4.0 research are tabulated in Table IV.

TABLE IV. SUBJECT AREA

\begin{tabular}{|l|c|c|}
\hline Subject Area & Frequency & \% \\
\hline Engineering & 830 & 66.08 \\
\hline Computer Science & 532 & 42.36 \\
\hline Business, Management and Accounting & 250 & 19.90 \\
\hline Decision Sciences & 206 & 16.40 \\
\hline Mathematics & 176 & 14.01 \\
\hline Materials Science & 157 & 12.50 \\
\hline Physics and Astronomy & 89 & 7.09 \\
\hline Social Sciences & 81 & 6.45 \\
\hline Economics, Econometrics and Finance & 58 & 4.62 \\
\hline Chemical Engineering & 53 & 4.22 \\
\hline Chemistry & 47 & 3.74 \\
\hline Energy & 43 & 3.42 \\
\hline Environmental Science & 38 & 3.03 \\
\hline Medicine & 13 & 1.04 \\
\hline Agricultural and Biological Sciences & 9 & 0.72 \\
\hline Earth and Planetary Sciences & 9 & 0.72 \\
\hline Pharmacology, Toxicology and Pharmaceutics & 9 & 0.72 \\
\hline Psychology & 8 & 0.64 \\
\hline Arts and Humanities & 6 & 0.48 \\
\hline Biochemistry, Genetics and Molecular Biology & 5 & 0.40 \\
\hline Multidisciplinary & 3 & 0.24 \\
\hline Nursing & 1 & 0.08 \\
\hline
\end{tabular}

\section{E. Keywords Analysis}

The author keywords were mapped with VOSviewer, a software tool for constructing and visualizing bibliometric networks. Figure 2 presents a network visualization of the author keywords in which color, square size, font size, and thickness of connecting lines were used to present the relationships with other keywords. For example, keywords with the same color were commonly listed together. So, in this study, for example, Industry 4.0, manufacturing, production, digital transformation, digitalization, and automation have a similar color (red) suggesting these keywords have a close relation and usually cooccur together.

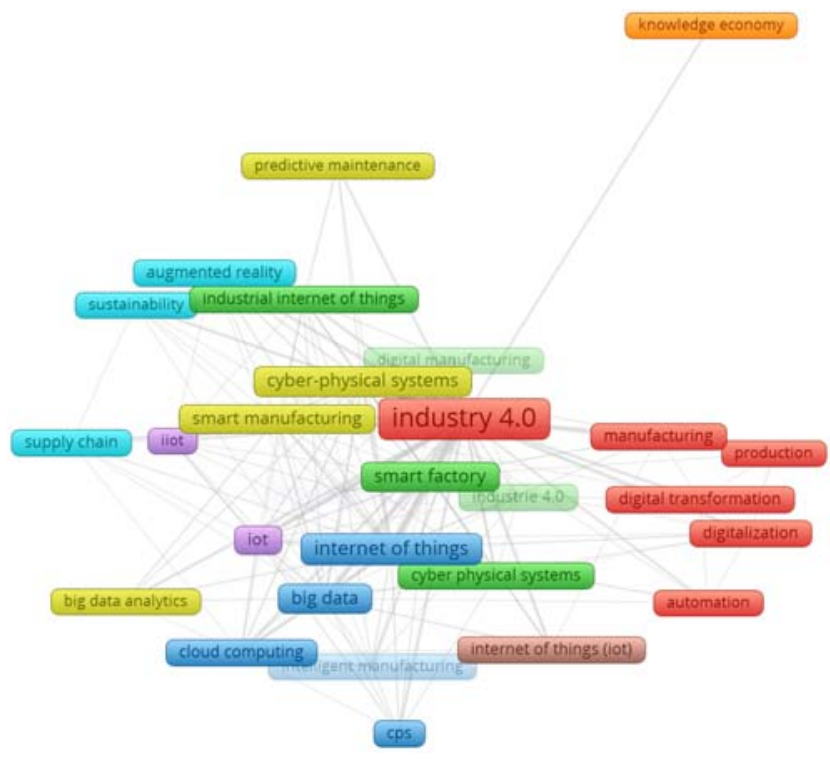

Fig. 2. Keyword Map

Based on the number of occurrences (after conducting data cleaning on the author keywords), keywords such as the Internet of Things (IoT) and Cyber-Physical Systems (CPS) were encountered as the most used keywords in the Industry 4.0 study. The top 20 keywords used in the Industry 4.0 research are shown in Table V.

TABLE V. KEYWORDS

\begin{tabular}{|c|l|c|}
\hline Rank & Keywords & Frequency \\
\hline 1 & internet of things (IoT) & 151 \\
\hline 2 & cyber-physical systems (CPS) & 101 \\
\hline 3 & big data & 48 \\
\hline 4 & smart factory & 47 \\
\hline 5 & industry 4.0 & 46 \\
\hline 6 & smart manufacturing & 38 \\
\hline 7 & industrial internet of things (IIoT) & 35 \\
\hline 8 & cloud computing & 20 \\
\hline 9 & cyber-physical system & 19 \\
\hline 10 & digitalization & 19 \\
\hline 11 & augmented reality & 17 \\
\hline 12 & big data analytics & 14 \\
\hline 13 & digital transformation & 14 \\
\hline 14 & manufacturing & 14 \\
\hline 15 & supply chain & 14 \\
\hline 16 & sustainability & 12 \\
\hline 17 & intelligent manufacturing & 11 \\
\hline 18 & automation & 10 \\
\hline 19 & digital manufacturing & 10 \\
\hline 20 & predictive maintenance & 10 \\
\hline 21 & production & 10 \\
\hline
\end{tabular}

\section{F. Geographical Distribution}

Researchers from 69 different countries contributed to the publication of retrieved documents. Top 20 countries contributed to the publications in Industry 4.0 are listed in Table VI. Germany was ranked first with a total of 404 documents 
followed by Italy (82), China (79) and the United Kingdom (UK) (74). In terms of the number of total citations by country, Germany was ranked first with a total of 1858 citations followed by United States (US) (1073).

TABLE VI. TOP 20 COUNTRIES CONTRIBUTED TO THE PUBLICATIONS

\begin{tabular}{|c|l|c|c|}
\hline Rank & Country & Total Publications & Total Citations \\
\hline 1 & Germany & 404 & 1858 \\
\hline 2 & Italy & 82 & 240 \\
\hline 3 & China & 79 & 525 \\
\hline 4 & United Kingdom & 74 & 364 \\
\hline 5 & Spain & 56 & 295 \\
\hline 6 & United States & 53 & 1073 \\
\hline 7 & Austria & 51 & 87 \\
\hline 8 & Russian Federation & 51 & 229 \\
\hline 9 & Portugal & 47 & 98 \\
\hline 10 & Taiwan & 37 & 146 \\
\hline 11 & Czech Republic & 36 & 92 \\
\hline 12 & Poland & 35 & 107 \\
\hline 13 & Brazil & 33 & 116 \\
\hline 14 & France & 30 & 106 \\
\hline 15 & India & 22 & 31 \\
\hline 16 & Sweden & 22 & 914 \\
\hline 17 & Hungary & 16 & 30 \\
\hline 18 & Slovakia & 15 & 26 \\
\hline 19 & Canada & 13 & 45 \\
\hline 20 & Switzerland & 13 & 94 \\
\hline
\end{tabular}

\section{G. Number of Author}

Table VII shows the number of authors per documents. A total of $309(24.6 \%)$ documents were single-authored publications, while the remaining documents were multiauthored publications.

TABLE VII. AUTHOR COUNT

\begin{tabular}{|c|c|c|}
\hline Author Count & Frequency & Percent \\
\hline 0 & 22 & 1.75 \\
\hline 1 & 309 & 24.60 \\
\hline 2 & 248 & 19.75 \\
\hline 3 & 245 & 19.51 \\
\hline 4 & 224 & 17.83 \\
\hline 5 & 99 & 7.88 \\
\hline 6 & 58 & 4.62 \\
\hline 7 & 26 & 2.07 \\
\hline 8 & 13 & 1.04 \\
\hline 9 & 5 & 0.40 \\
\hline 10 & 5 & 0.40 \\
\hline 13 & 1 & 0.08 \\
\hline 15 & 1 & 0.08 \\
\hline Total & 1256 & 100.00 \\
\hline
\end{tabular}

Several documents gathered from the Scopus database had no information available on the author's details. Further investigation conducted to get the information about the authors however it was unsuccessful. Assuming all these documents were written by one author, a mean collaboration index of Industry 4.0 research equals 3.65 authors per document.

\section{H. Citation Analysis}

We used Harzing's Publish or Perish software to seek the citation metrics for the retrieved data. Data gathered from the Scopus database has been imported into this software to generate the citation metric as well as the total citation for each document based on Google Scholar citations. Table VIII summaries the citation metrics for the retrieved documents as at $7^{\text {th }}$ October 2018. The summary includes the total number of citations with their citation per year, citations per paper, and citations per author.

TABLE VIII. METRICS

\begin{tabular}{|l|l|}
\hline Reference date: & $7 / 10 / 1821: 09$ \\
\hline Publication years: & $2012-2019$ \\
\hline Citation years: & $6(2012-2018)$ \\
\hline Papers: & 1256 \\
\hline Citations: & 5059 \\
\hline Citations/year: & 843.17 \\
\hline Citations/paper: & $4.03(*$ count $=58)$ \\
\hline Citations/author: & 1892.72 \\
\hline Papers/author: & 606.69 \\
\hline Authors/paper: & $2.94 / 3.0 / 1(\mathrm{mean} / \mathrm{median} / \mathrm{mode})$ \\
\hline Age-weighed citation rate: & $2777.50(\mathrm{sqrt}=52.70), 1037.09 /$ author \\
\hline Hirsch h-index: & $32(\mathrm{a}=4.94, \mathrm{~m}=5.33$, \\
& 2849 cites $=56.3 \%$ coverage $)$ \\
\hline Egghe g-index: & $58(\mathrm{~g} / \mathrm{h}=1.81,3391$ \\
& cites $=67.0 \%$ coverage $)$ \\
\hline PoP hI,norm: & 19 \\
\hline PoP hI,annual: & 3.17 \\
\hline
\end{tabular}

Top 20 cited articles in the field of Industry 4.0 were listed in Table IX. An article entitled "A Cyber-Physical Systems architecture for Industry 4.0-based manufacturing systems" by Lee, Bagheri, and Kao [7] received the highest citation (based on Scopus database) with a total of 583 citations (194 citations per year). Based on the total citations counted by Google Scholar as at $7^{\text {th }}$ October 2018, the same paper also obtained the highest number of citations with the total of 1013 citations and 337.67 citations per year.

TABLE IX. TOP 20 CITED ARTICLES IN INDUSTRY 4.0 STUdY

\begin{tabular}{|c|l|l|c|l|c|c|c|c|}
\hline No & Document title & Authors & Year & Source & $\begin{array}{c}\text { Cited } \\
\text { by }\end{array}$ & $\begin{array}{l}\text { Cites } \\
\text { per } \\
\text { Year }\end{array}$ & $\begin{array}{c}\text { GS } \\
\text { Cites }\end{array}$ & $\begin{array}{c}\text { GS } \\
\text { Cites } \\
\text { per } \\
\text { Year }\end{array}$ \\
\hline 1 & $\begin{array}{l}\text { A Cyber-Physical Systems architecture for } \\
\text { Industry 4.0-based manufacturing systems }\end{array}$ & $\begin{array}{l}\text { Lee, J., Bagheri, } \\
\text { B., Kao, H.-A. [7] }\end{array}$ & 2015 & Manufacturing Letters & 583 & 194 & 1013 & 337.67 \\
\hline 2 & $\begin{array}{l}\text { Service innovation and smart analytics for } \\
\text { Industry 4.0 and big data environment }\end{array}$ & $\begin{array}{l}\text { Lee, J., Kao, H.- } \\
\text { A., Yang, S. [8] }\end{array}$ & 2014 & Procedia CIRP & 272 & 68 & 514 & 128.5 \\
\hline 3 & $\begin{array}{l}\text { Industry 4.0 } \\
\text { Kemper, H.-G., Feld, } \\
\text { T., Hoffmann, M. [9] }\end{array}$ & 2014 & $\begin{array}{l}\text { Business and Information } \\
\text { Systems Engineering }\end{array}$ & 245 & 61 & 510 & 127.5 \\
\hline 4 & $\begin{array}{l}\text { Cyber physical systems in the context of } \\
\text { Industry 4.0 }\end{array}$ & \begin{tabular}{l} 
Jazdi, N. [10] \\
\hline
\end{tabular} & $\begin{array}{l}\text { Proceedings of 2014 IEEE } \\
\text { International Conference on }\end{array}$ & 109 & 27 & 230 & 57.5 \\
\hline
\end{tabular}




\begin{tabular}{|c|c|c|c|c|c|c|c|c|}
\hline No & Document title & Authors & Year & Source & $\begin{array}{c}\text { Cited } \\
\text { by }\end{array}$ & $\begin{array}{l}\text { Cites } \\
\text { per } \\
\text { Year }\end{array}$ & $\begin{array}{l}G S^{a} \\
\text { Cites }\end{array}$ & $\begin{array}{l}\text { GS } \\
\text { Cites } \\
\text { per } \\
\text { Year }\end{array}$ \\
\hline & & & & $\begin{array}{l}\text { Automation, Quality and Testing, } \\
\text { Robotics, AQTR } 2014\end{array}$ & & & & \\
\hline 5 & $\begin{array}{l}\text { Smart factories in Industry } 4.0 \text { : A review of } \\
\text { the concept and of energy management } \\
\text { approached in production based on the } \\
\text { Internet of Things paradigm }\end{array}$ & $\begin{array}{l}\text { Shrouf, F., Ordieres, J., } \\
\text { Miragliotta, G. [11] }\end{array}$ & 2014 & $\begin{array}{l}\text { IEEE International Conference on } \\
\text { Industrial Engineering and } \\
\text { Engineering Management }\end{array}$ & 109 & 27 & 181 & 45.25 \\
\hline 6 & $\begin{array}{l}\text { Human-machine-interaction in the industry } \\
4.0 \text { era }\end{array}$ & $\begin{array}{l}\text { Gorecky, D., Schmitt, } \\
\text { M., Loskyll, } \\
\text { M., Zühlke, D. [12] }\end{array}$ & 2014 & $\begin{array}{l}\text { Proceedings - } 201412 \text { th IEEE } \\
\text { International Conference on } \\
\text { Industrial Informatics, INDIN } \\
2014\end{array}$ & 105 & 26 & 187 & 46.75 \\
\hline 7 & $\begin{array}{l}\text { Opportunities of Sustainable Manufacturing } \\
\text { in Industry } 4.0\end{array}$ & $\begin{array}{l}\text { Stock, T., Seliger, G. } \\
{[\mathrm{X}]}\end{array}$ & 2016 & Procedia CIRP & 99 & 50 & 205 & 102.5 \\
\hline 8 & $\begin{array}{l}\text { Software-Defined Industrial Internet of } \\
\text { Things in the Context of Industry } 4.0\end{array}$ & $\begin{array}{l}\text { Wan, J., Tang, S., Shu, } \\
\text { Z., Li, D., Imran, } \\
\text { M., Vasilakos, A.V. } \\
\text { [13] }\end{array}$ & 2016 & IEEE Sensors Journal & 93 & 47 & 148 & 74 \\
\hline 9 & $\begin{array}{l}\text { The future of industrial communication: } \\
\text { Automation networks in the era of the } \\
\text { internet of things and industry } 4.0\end{array}$ & $\begin{array}{l}\text { Wollschlaeger, M., } \\
\text { Sauter, T., Jasperneite, } \\
\text { J. [14] }\end{array}$ & 2017 & $\begin{array}{l}\text { IEEE Industrial Electronics } \\
\text { Magazine }\end{array}$ & 91 & 91 & 163 & 163 \\
\hline 10 & $\begin{array}{l}\text { Towards smart factory for industry } 4.0: \text { A } \\
\text { self-organized multi-agent system with big } \\
\text { data based feedback and coordination }\end{array}$ & $\begin{array}{l}\text { Wang, S., Wan, J., } \\
\text { Zhang, D., Li, } \\
\text { D., Zhang, C. [15] }\end{array}$ & 2016 & Computer Networks & 70 & 35 & 224 & 112 \\
\hline 11 & $\begin{array}{l}\text { Towards Industry } 4.0 \text { - Standardization as } \\
\text { the crucial challenge for highly modular, } \\
\text { multi-vendor production systems }\end{array}$ & $\begin{array}{l}\text { Weyer, S., Schmitt, } \\
\text { M., Ohmer, } \\
\text { M., Gorecky, D. [16] }\end{array}$ & 2015 & IFAC-PapersOnLine & 61 & 20 & 146 & 48.67 \\
\hline 12 & $\begin{array}{l}\text { Industry } 4.0 \text { - Potentials for creating smart } \\
\text { products: Empirical research results }\end{array}$ & $\begin{array}{l}\text { Schmidt, R., Möhring, } \\
\text { M., Härting, R.-C., } \\
\text { Reichstein, C., } \\
\text { Neumaier, P., } \\
\text { Jozinović, P. [17] }\end{array}$ & 2015 & $\begin{array}{l}\text { Lecture Notes in Business } \\
\text { Information Processing }\end{array}$ & 61 & 20 & 125 & 41.67 \\
\hline 13 & $\begin{array}{l}\text { A review of industrial wireless networks in } \\
\text { the context of Industry } 4.0\end{array}$ & $\begin{array}{l}\text { Li, X., Li, D., Wan, J., } \\
\text { Vasilakos, A.V., Lai, } \\
\text { C.-F., Wang, S. [18] }\end{array}$ & 2017 & Wireless Networks & 59 & 59 & 108 & 108 \\
\hline 14 & $\begin{array}{l}\text { A Categorical Framework of Manufacturing } \\
\text { for Industry } 4.0 \text { and beyond }\end{array}$ & $\begin{array}{l}\text { Qin, J., Liu, } \\
\text { Y., Grosvenor, R. [19] }\end{array}$ & 2016 & Procedia CIRP & 58 & 29 & 116 & 58 \\
\hline 15 & $\begin{array}{l}\text { Industry 4.0: Towards future industrial } \\
\text { opportunities and challenges }\end{array}$ & $\begin{array}{l}\text { Zhou, K., Liu, } \\
\text { T., Zhou, L. [20] }\end{array}$ & 2016 & $\begin{array}{l}2015 \text { 12th International } \\
\text { Conference on Fuzzy Systems } \\
\text { and Knowledge Discovery, FSKD } \\
2015\end{array}$ & 56 & 28 & 92 & 30.67 \\
\hline 16 & $\begin{array}{l}\text { Change through digitization-value creation } \\
\text { in the age of industry } 4.0 \text { (Book Chapter) }\end{array}$ & Kagermann, H. [21] & 2015 & $\begin{array}{l}\text { Management of Permanent } \\
\text { Change }\end{array}$ & 56 & 19 & 131 & 43.67 \\
\hline 17 & $\begin{array}{l}\text { Industry 4.0: A survey on technologies, } \\
\text { applications and open research issues }\end{array}$ & Lu, Y. [22] & 2017 & $\begin{array}{l}\text { Journal of Industrial Information } \\
\text { Integration }\end{array}$ & 54 & 54 & 120 & 120 \\
\hline 18 & $\begin{array}{l}\text { A dynamic model and an algorithm for short- } \\
\text { term supply chain scheduling in the smart } \\
\text { factory industry } 4.0\end{array}$ & $\begin{array}{l}\text { Ivanov, D., Dolgui, A., } \\
\text { Sokolov, B., Werner, } \\
\text { F., Ivanova, M. [23] }\end{array}$ & 2016 & $\begin{array}{l}\text { International Journal of } \\
\text { Production Research }\end{array}$ & 53 & 27 & 97 & 48.5 \\
\hline 19 & $\begin{array}{l}\text { Lean Automation enabled by Industry } 4.0 \\
\text { Technologies }\end{array}$ & $\begin{array}{l}\text { Kolberg, D., Zühlke, } \\
\text { D. [24] }\end{array}$ & 2015 & IFAC-PapersOnLine & 45 & 15 & 113 & 37.67 \\
\hline 20 & $\begin{array}{l}\text { Understanding the implications of } \\
\text { digitisation and automation in the context of } \\
\text { Industry 4.0: A triangulation approach and } \\
\text { elements of a research agenda for the } \\
\text { construction industry }\end{array}$ & $\begin{array}{l}\text { Oesterreich, T.D., } \\
\text { Teuteberg, F. [25] }\end{array}$ & 2016 & Computers in Industry & 44 & 22 & 100 & 50 \\
\hline
\end{tabular}

a. $\mathrm{GS}=$ Google Scholar

\section{CONCLUSION}

This paper presents a bibliometric review to gain a clearer insight into the trends, historical review, forecasts and contributions of the Industry 4.0 literature. The research on this topic started in 2012 and increased year by year since then. The number of publications drastically increased in 2017 with a total of 399 publications compared to 217 in 2016. It is expected the total number of publications in Industry 4.0 will increase more in 2018 where, as of October 2018, the total publications already reached 409 documents. Articles related to Industry 4.0 also were written by multiple authors with a mean collaboration index of 3.65 authors per article.

This study also reveals that the areas mostly covered in the Industry 4.0 research are related to IoT and CPS based on the keywords used by authors. Other potential topics worth exploring include big data, smart factory, smart manufacturing and the industrial internet of things (IIoT).

The geographic dispersion of the literature shows that Germany has the largest number of publications as well as influence in terms of the number of citations as compared to other developed countries such as the US and the UK. We 
propose that the research on Industry 4.0 should be conducted in other developing countries, as the impact on the technologies were globally affected.

Our study has a few limitations that are inherent to the database used. Thus, it should be emphasized that even though Scopus is one of the largest databases, there are still journals unindexed, and therefore publications in these journals might have been ignored. Furthermore, this study only focused on the topic related to Industry 4.0 based on the title of the documents. Thus, all the other literature that related to Industry 4.0 but not explicitly use it in the title was also excluded. It is also important to highlight that no search query is $100 \%$ perfect, false positive and false negative results may occur. The citation analysis presented in our study was based on data from Scopus and Google Scholar. The total number of publications and citations is only correct at the time of the search or the. Despite all these limitations, this study is among the first to analyze the detailed bibliometric indicators of the published literature in Industry 4.0 apart of the bibliometric study conducted by Trotta et al (2018) who discussed only keywords used in publications related to Industry 4.0 .

\section{ACKNOWLEDGMENT}

We would like to thank the anonymous reviewer for their constructive comments and suggestions to improve this paper.

\section{REFERENCES}

[1] IGI Global, "What is Bibliometric Analysis." [Online]. Available: https://www.igi-global.com/dictionary/bibliometric-analysis/2406. [Accessed: 06-Oct-2018].

[2] A. Pritchard, "Statistical bibliography or bibliometrics," J. Doc, vol. 25, no. 4, pp. 348-349, 1969

[3] J. F. Burnham, "Scopus database: a review," Biomed. Digit. Libr., vol. 3, no. 1, p. 1, Dec. 2006

[4] A. A. Chadegani et al., "A Comparison between Two Main Academic Literature Collections: Web of Science and Scopus Databases," Asian Soc. Sci., vol. 9, no. 5, Apr. 2013.

[5] Sweileh, W. M., Al-Jabi, S. W., AbuTaha, A. S., Zyoud, S. H., Anayah, F. M. A., \& Sawalha, A. F. (2017). Bibliometric analysis of worldwide scientific literature in mobile - health: 2006-2016. BMC Medical Informatics and Decision Making, 17(1), 72. https://doi.org/10.1186/s12911-017-0476-7

[6] D. Hofmann, R. Margull, P.-G. Dittrich, and E. Düntsch, "Smartphone green vision at dawn of industry 4.0," 2011 7th International Conference on MEMS, NANO and Smart Systems, ICMENS 2011, vol. 403-408. Technologie-und Innovationspark Jena GmbH, Wildenbruchstraße 15, D07745 Jena, Germany, pp. 4079-4083, 2012

[7] J. Lee, H.-A. Kao, and S. Yang, "Service innovation and smart analytics for Industry 4.0 and big data environment," in 6th CIRP Conference on Industrial Product Service Systems, IPSS 2014, 2014, vol. 16, pp. 3-8.

[8] Y. Cohen, M. Faccio, F. G. Galizia, C. Mora, and F. Pilati, "Assembly system configuration through Industry 4.0 principles: the expected change in the actual paradigms," IFAC-PapersOnLine, vol. 50, no. 1, pp. 1495814963, 2017.
[9] N. Jazdi, "Cyber physical systems in the context of Industry 4.0," in 2014 19th IEEE International Conference on Automation, Quality and Testing, Robotics, AQTR 2014, 2014.

[10] F. Shrouf, J. Ordieres, and G. Miragliotta, "Smart factories in Industry 4.0: A review of the concept and of energy management approached in production based on the Internet of Things paradigm," in 2014 IEEE International Conference on Industrial Engineering and Engineering Management, IEEM 2014, 2014, vol. 2015-Janua, pp. 697-701.

[11] D. Gorecky, M. Schmitt, M. Loskyll, and D. Zühlke, "Human-machineinteraction in the industry 4.0 era," in 12 th IEEE International Conference on Industrial Informatics, INDIN 2014, 2014, pp. 289-294.

[12] T. Stock and G. Seliger, "Opportunities of Sustainable Manufacturing in Industry 4.0," Procedia CIRP, vol. 40, pp. 536-541, 2016.

[13] J. Wan et al., "Software-Defined Industrial Internet of Things in the Context of Industry 4.0," IEEE Sens. J., vol. 16, no. 20, pp. 7373-7380, 2016.

[14] M. Wollschlaeger, T. Sauter, and J. Jasperneite, "The future of industrial communication: Automation networks in the era of the internet of things and industry 4.0," IEEE Ind. Electron. Mag., vol. 11, no. 1, pp. 17-27, 2017.

[15] S. Wang, J. Wan, D. Zhang, D. Li, and C. Zhang, "Towards smart factory for industry 4.0: A self-organized multi-agent system with big data based feedback and coordination," Comput. Networks, vol. 101, pp. 158-168, 2016.

[16] S. Weyer, M. Schmitt, M. Ohmer, and D. Gorecky, "Towards Industry 4.0 - Standardization as the crucial challenge for highly modular, multivendor production systems," IFAC-PapersOnLine, vol. 48, no. 3, pp. 579-584, 2015.

[17] R. Schmidt, M. Möhring, R.-C. Härting, C. Reichstein, P. Neumaier, and P. Jozinović, "Industry 4.0 - Potentials for creating smart products: Empirical research results," 18th International Conference on Business Information Systems, BIS 2015, vol. 208. Springer Verlag, Business Information Systems, Aalen University, Beethovenstr. 1, Aalen, 73430 Germany, pp. 16-27, 2015

[18] X. Li, D. Li, J. Wan, A. V Vasilakos, C.-F. Lai, and S. Wang, "A review of industrial wireless networks in the context of Industry 4.0," Wirel. Networks, vol. 23, no. 1, pp. 23-41, 2017.

[19] J. Qin, Y. Liu, and R. Grosvenor, "A Categorical Framework of Manufacturing for Industry 4.0 and beyond," in 6th International Conference on Changeable, Agile, Reconfigurable and Virtual Production, CARV 2016, 2016, vol. 52, pp. 173-178.

[20] K. Zhou, T. Liu, and L. Zhou, "Industry 4.0: Towards future industrial opportunities and challenges," in 12th International Conference on Fuzzy Systems and Knowledge Discovery, FSKD 2015, 2016, pp. 2147-2152.

[21] H. Kagermann, "Change through digitization-value creation in the age of industry 4.0," in Management of Permanent Change, acatech NATIONAL ACADEMY OF SCIENCE AND ENGINEERING, Unter den Linden 14, Berlin, 10117, Germany: Springer Science+Business Media, 2015, pp. 23-45.

[22] Y. Lu, "Industry 4.0: A survey on technologies, applications and open research issues," J. Ind. Inf. Integr., vol. 6, pp. 1-10, 2017.

[23] D. Ivanov, A. Dolgui, B. Sokolov, F. Werner, and M. Ivanova, "A dynamic model and an algorithm for short-term supply chain scheduling in the smart factory industry 4.0," Int. J. Prod. Res., vol. 54, no. 2, pp 386-402, 2016.

[24] D. Kolberg and D. Zühlke, "Lean Automation enabled by Industry 4.0 Technologies," IFAC-PapersOnLine, vol. 48, no. 3, pp. 1870-1875, 2015.

[25] T. D. Oesterreich and F. Teuteberg, "Understanding the implications of digitisation and automation in the context of Industry 4.0: A triangulation approach and elements of a research agenda for the construction industry," Comput. Ind., vol. 83, pp. 121-139, 2016. 